\title{
FARMER DECISION MAKING AND ITS EFFECT ON SUBALPINE GRASSLAND SUCCESSION IN THE GIANT MTS., CZECH REPUBLIC
}

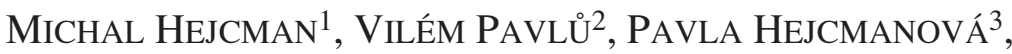 \\ JAN GAISLER $^{2}$, JOSEF HAKL ${ }^{1}$, OTTO RAUCH ${ }^{4}$ \\ ${ }^{1}$ Czech University of Agriculture in Prague \\ Department of Ecology and Environment \\ Kamýcká 129, CZ 16521 Prague 6 - Suchdol, Czech Republic \\ e-mail: hejcman@af.czu.cz \\ ${ }^{2}$ Research Institute of Crop Production, Prague-Ruzyně \\ Grassland Research Station \\ Rolnická 6, CZ 46001 Liberec, Czech Republic \\ ${ }^{3}$ Czech University of Agriculture in Prague \\ Institute of the Tropics and Subtropics \\ Kamýcká 129, CZ 16521 Prague 6 - Suchdol, Czech Republic \\ ${ }^{4}$ Institute of Botany, Academy of Sciences of the Czech Republic \\ Dukelská 145, CZ 37901 Třeboň, Czech Republic
}

(Received: August 25, 2005. Accepted: March 20, 2006)

\begin{abstract}
Nitrogen deposition is generally considered as a main reason for many recent plant expansions, but management changes are often not taken into account. Understanding the effects of agriculture management in the past can be decisive in the explanation of plant expansions at present. In order to understand the spread of Molinia caerulea and Calamagrostis villosa into Nardus stricta dominated subalpine grassland in the Giant Mts. (Krkonoše, Karkonosze), we undertook an experiment to explain farmer decision making and we discussed its effect on grassland succession. We measured mowing productivity, yields, biomass quality and nutrient removal in N. stricta, M. caerulea, and $C$. villosa dominated swards. With regard to defoliation management performed on the subalpine grasslands for at least 500 years and cancelled after the Second World War, we found the following results and conclusions. 1. Mowing productivity, yield and forage quality were lowest in the N. stricta sward, therefore farmers preferred to harvest $C$. villosa and $M$. caerulea stands if they had the possibility to select a sward for mowing. 2. Removal of all nutrients was the lowest in the $N$. stricta sward. With respect to these facts, the competitive advantage of $N$. stricta is obvious under long-term scything without fertilization. Consequently, the recent increase of defoliation sensitive species $M$. caerulea and $C$. villosa above the timber line must be evaluated with respect to both: termination of agricultural activities and recent nitrogen deposition.
\end{abstract}

KEY WORDS: forage quality, mowing productivity, Nardo-Caricion rigidae, nutrient removal, grassland succession.

\section{INTRODUCTION}

The area of natural grasslands is negligible in the Czech Republic. Nardus stricta dominated subalpine meadows (Nardo-Caricion rigidae alliance), for instance, are considered natural by many researches in the Giant Mts. (Krkonoše and Karkonosze in Czech and Polish) despite of their presumed enlargement by cutting and grazing in the past (Jeník 1961; Štursa 1983; Štursová 1985; Krahulec 1985). Lokvenc $(1960,2001)$, on the other hand, considered $\mathrm{Na}$ - rdus stricta grasslands as semi-natural arisen by oligotrophisation of plant communities caused by long-term grazing and hay-making regimes after removal of Pinus mugo shrubs. Hendrych (2001) presumed a quick increase of $N$. stricta as a consequence of agricultural exploitation here during the 17th and 18th centuries. Hejcman et al. (2005) confirmed the ability of $N$. stricta to colonize bare ground in subalpine conditions thus they concluded the possibility of $N$. stricta spread due to cattle grazing and hay making. Although all the above mentioned studies discussed the ef- 
fect of agriculture on the sward structure of subalpine grasslands, no study directly analyzed the available historical data on biomass removal or number of grazing animals above the upper tree line and therefore all conclusions about the development of this community have been at a theoretical level to date.

To assess the agricultural impact on the landscape, it is necessary to take into account the principles of farmer decision making. Generally, farmers in grassland areas need to maximize their profitability by increasing the weight gain of livestock or milk production, but each animal is able to ingest only a limited amount of biomass. Farmers therefore demand a maximum quality of herbage for feeding. Forage quality (syn. nutritive value) is determined mainly by crude protein, crude fibre, energy content, minerals ( $\mathrm{Ca}$, $\mathrm{P}, \mathrm{Mg}, \mathrm{K}, \mathrm{Na}$ ), and by the content of antinutritive compounds in the plant biomass. Nutritive values are strictly species dependent and are affected by other factors such as fertilization, minerals content in the soil, plant phenology, etc. (Schellberg et al. 1999; Homolka 2000; Pavlů, Velich 2001; Hejduk, Doležal 2004; Pavlů et al. 2006). N. stricta, for example, is known for its low crude protein content and high content of antinutritive silicate compounds decreasing biomass digestibility (Jančovič, Holúbek 1999).

Production limits, such as area available for forage growth and time for its harvest, are a second criterion in farmer decision making. If the limiting factor is time and not area, the farmer seeks to increase harvest efficiency by mowing stands with the highest biomass production and does not manage the least productive ones. In the case of subalpine grasslands, for example, this leads to cutting Calamagrostion villosae and neglecting Nardo-Caricion rigidae grasslands. If the opposite is true and the area is limited, the farmer has to harvest the total available area without respect to yields, harvest productivity, and biomass quality. Bartoš $(1991,1992)$ described the yields on N. stricta grasslands in the eastern part of the Giant Mts. in the 19th century. The biomass production was so low that to obtain yields of at least 200 to $800 \mathrm{~kg}^{*} \mathrm{ha}^{-1}$ of dry matter (DM), the area could be mown only once per 2-3 years. Obviously, farmers in the 19th century were not able to select more productive swards and had to harvest the entire available area without respect to time and mowing productivity. It is evident that such conditions led to the highest possible defoliation.

The defoliation management of subalpine N. stricta dominated grasslands ceased after World War II. During the long-term monitoring of these grasslands in recent decades, an increase of Calamagrostis villosa and Molinia caerulea was recorded (Štursová 1985; Wágnerová 1991; Lokvenc 1996; Fabiszewski, Wojtun 2001) but no study was focused on reasons for that increase. Higher nitrogen deposition in the last decades was generally accepted as the main reason, without respect to previous intensive defoliation management, similarly as for the expansion of $M$. caerulea in Western Europe (Marrs et al. 2004; Tomassen et al. 2004). The defoliation sensitivity of $C$. villosa above the upper tree limit was investigated by Hejcman et al. (2005). Results of the study are in accordance with Lokvenc's theory (Lokvenc 1978, 2001) predicting C. villosa retreat after an introduction of regular agricultural activities in the past. The revealed defoliation sensitivity of $C$. villosa led farmers consequently to at least partly consider its present in- crease as a long-term succession of the sward after cessation of regular management.

With respect to defoliation management performed above the upper tree limit before World War II, we analyzed farmers' preferences for harvesting particular vegetation types to determine possible effects on the vegetation succession there. The aim of this study was therefore to answer the following question: which grassland did the farmer prefer to harvest when he started to manage the subalpine zone of the Giant Mts.? In our study we compared biomass yields, mowing productivity, nutritive values and nutrient removal in $N$. stricta, $C$. villosa and $M$. caerulea dominated subalpine swards. All these parameters determine the farmer's behaviour.

\section{MATERIALS AND METHODS}

\section{Study site}

The study was performed on the Harrachov and Labská meadows as the increase of $C$. villosa and $M$. caerulea in $N$. stricta dominated swards is the most remarkable there. The area of the investigated locality was approximately 650 ha. The site lies above the upper tree limit in the western part of the Giant Mts. $\left(50^{\circ} 45^{\prime} 32^{\prime}\right.$ ' N, $15^{\circ} 32^{\prime} 28^{\prime}$ ' W, Czech Republic). The altitude of the study site varies from the 1340 to $1380 \mathrm{~m}$; The soil types are podzols developed on medium grain porphyric granite or granodiorite. The mean annual temperature is $2^{\circ} \mathrm{C}$ and the mean annual precipitation is $1380 \mathrm{~mm}$ (Vrbatova bouda Meteorological Station). According to phytocenological nomenclature (Krahulec et al. 1996; Kočí 2001), the N. stricta dominated grasslands belong to the Nardo-Caricion rigidae alliance, C. villosa dominated grasslands to the Calamagrostion villosae alliance, and $M$. caerulea dominated grasslands to the Carici fylae-Nardetum subas. typicum community. Nomenclature of vascular plants follows Kubát et al. (2002).

\section{Historical background of the site and agriculture}

According to Lokvenc (2001), the investigated area has been farmed for at least 500 years. However, mowing and grazing began to be more intensive during the 16th century when the Dvoračky settlement was established. The first written record about hay-making above the timber line in the Giant Mountains dates back to 1609 (Lokvenc 1978). Our area laid on the unstable border between two hostile dominions, therefore the first written record about hay-making in the Harrachov and Labská meadow dates back to 1668 when a farmer from one dominion was captured during hay making by people from the second one. A converse situation provided further evidence for grassland harvesting in 1688. Unstable ownership of the land and fear from imprisonment resulted probably in the harvest of only the most productive sites and ruthless exploitation of Pinus mugo stands for firewood. The situation stabilized in 1710 and regular controlled cattle grazing, hay making, and firewood collection started at the locality. The first evidence about grazing in the study area comes from 1688, when 50 cows and 80 goats from Dvorské boudy settlement were kept to graze probably the southern part of the study area. Farming reached its peak in the 18th century and restrictions of grazing were recorded in the 19th century. Accor- 
ding to various sources based predominantly on economic records, 230-340 cows were kept at the pasture and 5 haylofts were built in the investigated area during the 18th century. Later, hay making prevailed and the area rented out by authorities for mowing was 550 ha in the second half of the 19th century (Schmid 1879). Hay-making and therefore all agricultural activities were definitively abandoned after World War II. Hay making of subalpine grasslands at the end of the 19th century is shown in Figure 1. Figure 2 documents hay making in the investigated area before World War II.

\section{Mowing productivity and yields}

Three plots dominated by N. stricta, C. villosa, and $M$. caerulea were selected in the study area and harvested according to traditional hay-making at the beginning of $\mathrm{Au}-$ gust 2003. All analyses were performed in three replications. Mean coverage of plants and their biomass percentage in the mown samples of three stands of each dominant are given in Table 1. To eliminate the effect of skill, two experienced mowers were employed for the cutting of the selected plots. To adapt to the investigated sward, each worker performed several minutes of mowing before the mowing productivity measurement. Mowing productivity was expressed as mown area and obtained biomass in dry matter per two minutes of work. We used one sharp scythe of the same length and with the same kind of handle as traditional. Traditional scythes used for the mowing of the investigated area are shown in Figure 3. Yields were determined by harvesting $1 \mathrm{~m}^{2}$ in each selected stand. The height of the stubble was $3 \mathrm{~cm}$. Fresh biomass was weighed in the field, then a mixed sample was taken and dried at approximately $80^{\circ} \mathrm{C}$ under laboratory conditions, and field weights were recalculated into dry matter. In the case of $N$. stricta biomass, we removed litter of more than one year old.

\section{Biomass quality}

We investigated the biomass quality of dominant species only. We used this approach because the biomass percentage of other species was lower than $1 \%$ (Table 1) and therefore negligible. The second reason was that the forage qua-
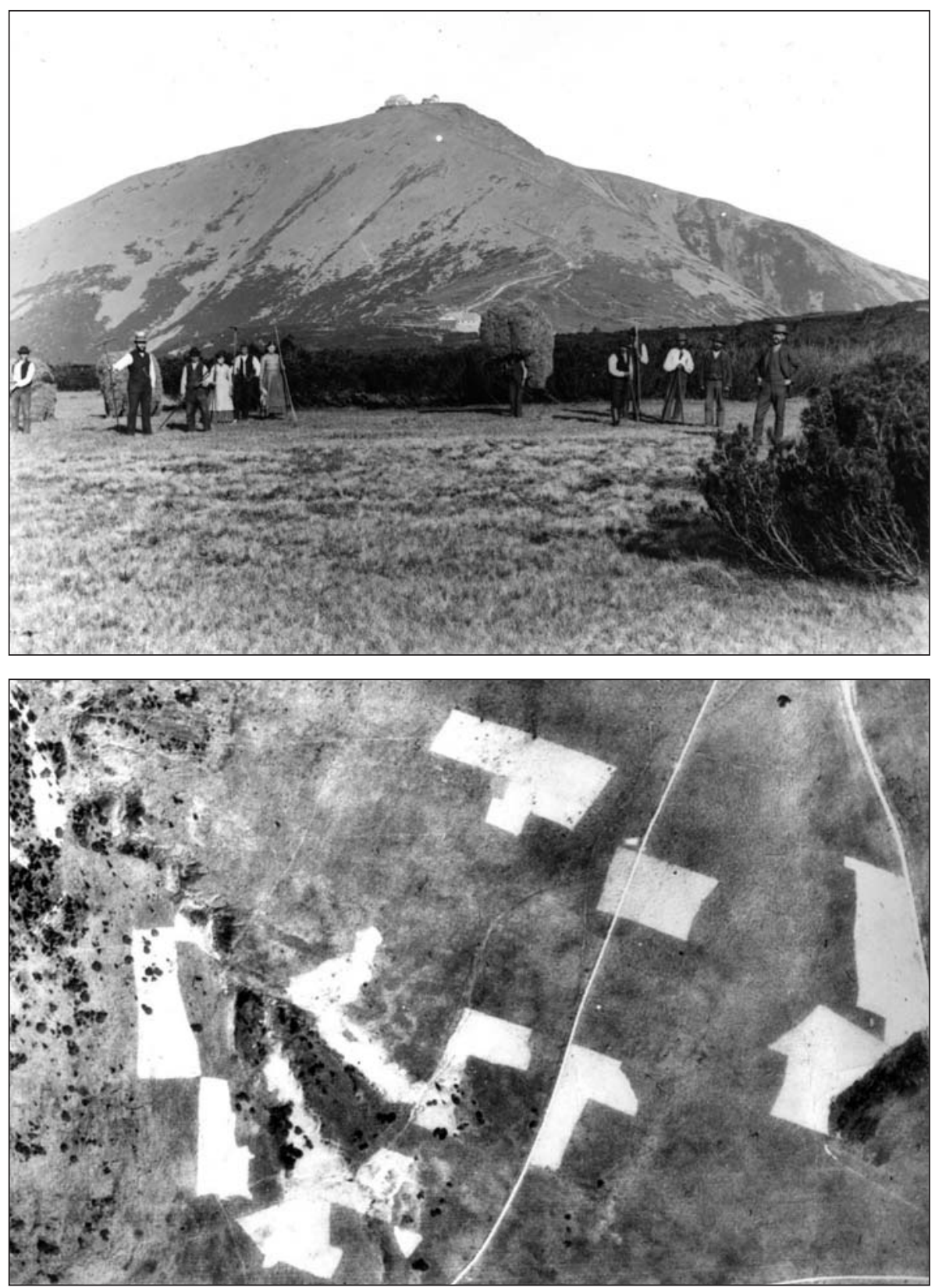

Fig. 1. Hay making above the upper tree limit in the Giant Mountains at the end of the 19th century. Women carried up to $50 \mathrm{~kg}$ and men up to $70 \mathrm{~kg}$ of hay over a distance of $12 \mathrm{~km}$ (Photo: archive KRNAP).
Fig. 2. Aerial photograph of study area (Harrachov meadow) taken in 1936. Light patches indicate freshly mown plots. Mowing of the same place was possible only once per two or three years. Hay-making in the forests close to the upper tree limit is visible in the upper left hand corner of the photograph (Photo: archive KRNAP). 
TABLE 1. Mean coverage of plants (cover) and their biomass percentage (biomass) in the mown samples on Nardus stricta (Nar.), Calamagrostis villosa (Cal.), and Molinia caerulea (Mol.) dominated swards.

\begin{tabular}{|c|c|c|c|c|c|c|}
\hline Species & Nar. cover & Nar. biomass & Cal. cover & Cal. biomass & Mol. cover & Mol. biomass \\
\hline Anthoxanthum alpinum & 1 & 0.03 & 0.5 & 0.04 & & \\
\hline Avenella flexuosa & 5 & 0.1 & 5 & 0.11 & 3 & 0.2 \\
\hline Calamagrostis villosa & 2 & 0.24 & 95 & 99.7 & & \\
\hline Carex bigelowii & 0.5 & 0.01 & & & & \\
\hline Carex pilulifera & 0.5 & 0.01 & & & & \\
\hline Galium saxatile & 2 & 0.03 & 1 & 0.1 & & \\
\hline Luzula sudetica & 0.5 & 0.01 & & & & \\
\hline Molinia caerulea & & & & & 97 & 99.8 \\
\hline Nardus stricta & 90 & 99.56 & & & & \\
\hline
\end{tabular}

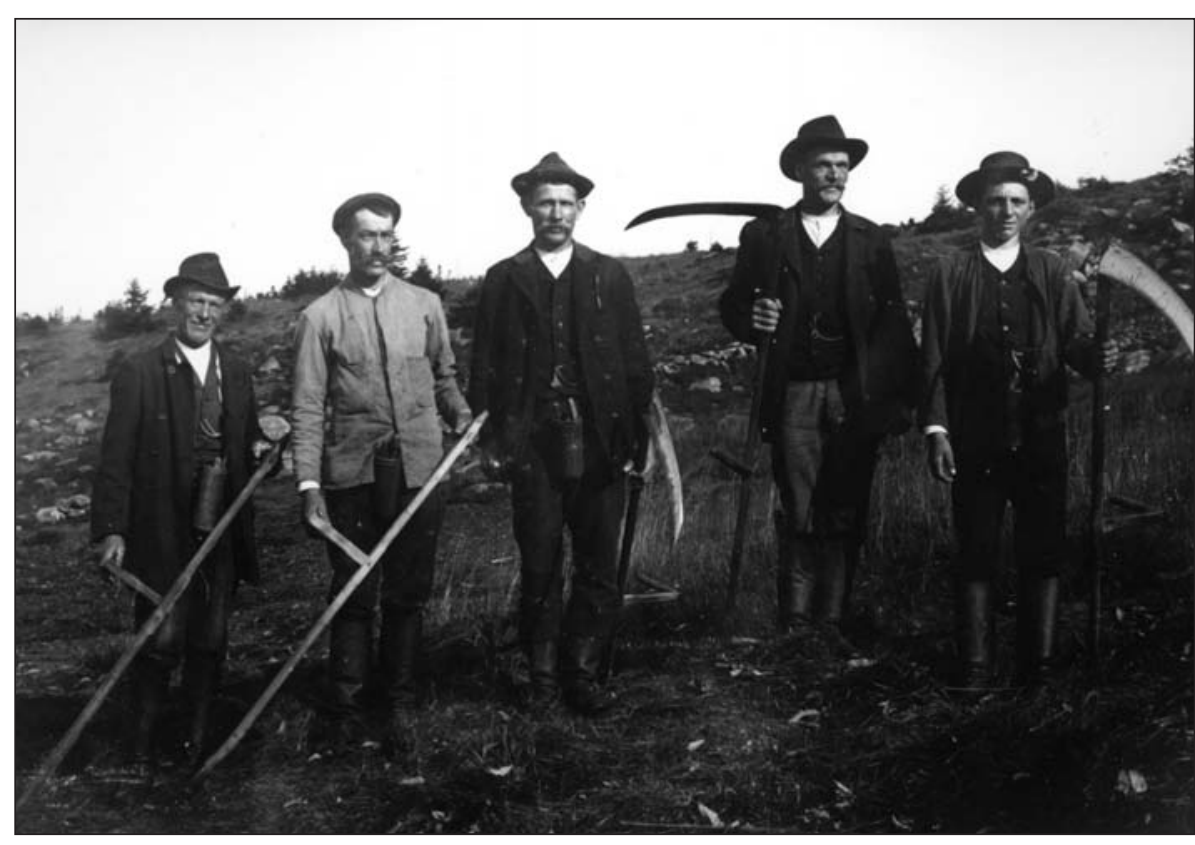

Fig. 3. Mowers of subalpine grasslands in the Western Giant Mountains. Mowing of Nardus stricta dominated grasslands was very difficult and extra sharp and short scythes were necessary for it (Photo: archive KRNAP). lity of $C$. villosa has not yet been distinguished under central Europe conditions and the results will serve as a comparison for further studies. Biomass samples were dried and analyzed for nutrients and minerals. Dry matter (DM), crude protein $(\mathrm{CP})$, and crude fibre $(\mathrm{CF})$ were determined by the Weende analyses method (AOAC 1984). The gross energy (GE) was measured by using the automatic adiabatic calorimeter LAGET MS 10 A. Minerals and ash content was analyzed by colorimetry, photometry, and by atomic absorption spectrometry.

\section{Nutrient removal}

Nutrient removal was calculated by multiplying yield by nutrient content in the biomass and expressed in kilograms per ha.

\section{Data analysis}

One way ANOVA was used to evaluate the collected data. In the case of a significant result, we performed the Tu- key HSD test for post-hoc comparisons. All analyzes were performed in the STATISTICA (version 6.0) program.

\section{RESULTS}

\section{Mowing productivity and yields}

The mowing productivity expressed as mown area per two minutes was the highest in the $C$. villosa dominated stand and was significantly different from $N$. stricta and $M$. caerulea stands. Results of the performed analyses are shown in Table 2. The data were visualized in the form of box plots (Fig. 4). The mean mowing productivity per two minutes was $6.5,6.5$ and $9.9 \mathrm{~m}^{2}$ in $N$. stricta, $M$. caerulea and $C$. villosa stands, respectively. From the practical point of view the most decisive for farmers is mowing productivity expressed as obtained dry matter per mowing time. Obtained dry matter per two minutes of mowing was 2.7, 6.1 , and $10.4 \mathrm{~kg}$ on $N$. stricta, M. caerulea, and C. villosa

TABLE 2. Results of ANOVA analyses of mowing productivity and dry matter yield of Nardus stricta, Calamagrostis villosa and Molinia caerulea dominated stands. Tukey HSD - indicate significant differences between investigated vegetation types, $\mathrm{N}-$ Nardus stricta, C - Calamagrostis villosa and M Molinia caerulea dominated stands. Significant results are bold faced. Degrees of freedom were 2 in all performed analyses.

\begin{tabular}{lcrrr}
\hline Variable & F-ratio & P-value & Tukey HSD \\
\hline Mowing productivity - Area & 10.7 & $\mathbf{0 . 0 0 4}$ & N-C, M-C \\
Mowing productivity - Dry matter & 21.4 & $\mathbf{< 0 . 0 0 1}$ & N-C, N-M, M-C \\
Dry matter yield & 17.0 & $\mathbf{0 . 0 0 3}$ & N-C, N-M & \\
\hline
\end{tabular}



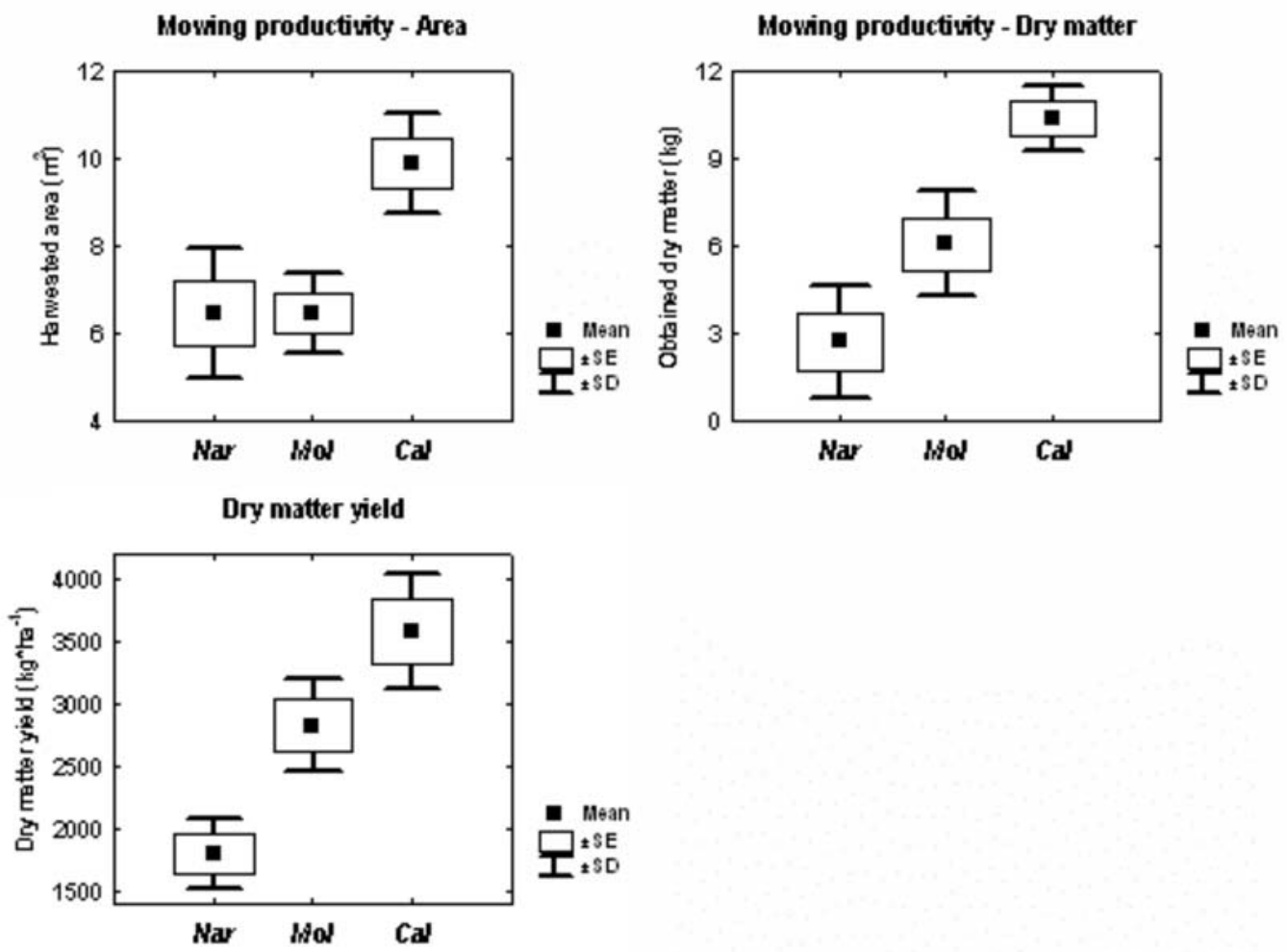

Fig. 4. Mowing productivity as the harvested area and obtained dry matter per 2 minutes of mowing. The bottom graph shows dry matter yields in Nardus stricta (Nar), Molinia caerulea (Mol) and Calamagrostis villosa (Cal) dominated swards.

stands, respectively. All differences were significant and indicated the lowest biomass harvest in $N$. stricta grassland. Mowing productivity in $M$. caerulea and C. villosa stands was more than twice and more than three times higher in comparison with the $N$. stricta stand, respectively. Therefore, to obtain the same amount of hay from a $N$. stricta sward as from the other two swards, farmers had to work more than two and three times longer. Dry matter yield was 1800,2827 , and $3580 \mathrm{~kg}^{*} \mathrm{ha}^{-1}$ in N. stricta, $M$. caerulea, and $C$. villosa stands, respectively. Significant differences in yield were found between N. stricta $-C$. villosa and N. stricta - M. caerulea. Dry matter yields indicated that the farmer had to mow almost twice as large an area of $N$. stricta grassland to obtain the same amount of hay as from the $C$. villosa sward.

\section{Biomass quality}

We revealed significant ANOVA results for all investigated parameters with the exception of sodium content.
Results of the performed analyses are shown in Table 3 and in Figures 5 and 6. Calcium, magnesium, phosphorus, and potassium content in N. stricta were significantly different from $M$. caerulea and $C$. villosa, but the differences between $M$. caerulea and $C$. villosa were not significant. Silicate, ash, and crude protein content were significantly different between all combinations of investigated species. Nitrate nitrogen content differed significantly between $N$. stricta $-C$. villosa and M. caerulea $-C$. villosa. Crude fiber content was significantly different only between $N$. stricta and $C$. villosa.

Crude protein, similarly as gross energy content, was the highest in the biomass of $M$. caerulea, followed by $C$. villo$s a$ and the lowest in $N$. stricta. The revealed mean crude protein content was $90.87,147.97$, and $99.73 \mathrm{~g}^{*} \mathrm{~kg}^{-1}$, mean crude fibre content was $316,309.17$ and $300.17 \mathrm{~g}^{*} \mathrm{~kg}^{-1}$, and mean gross energy content $17,466,18,342$, and 17,575 $\mathrm{kJ}^{*} \mathrm{~kg}^{-1}$ in $N$. stricta, $M$. caerulea and $C$. villosa biomass, respectively.

TABLE 3. Results of ANOVA analyses of nutrient contents in the biomass of Nardus stricta, Calamagrostis villosa and Molinia caerulea. For abbreviations see Table 2 .

\begin{tabular}{|c|c|c|c|}
\hline Variable & F-ratio & P-value & Tukey HSD \\
\hline Calcium content & 14.5 & 0.005 & $\mathrm{~N}-\mathrm{M}, \mathrm{N}-\mathrm{C}$ \\
\hline Magnesium content & 37.2 & $<0.001$ & N-M, N-C \\
\hline Phosphorus content & 15.4 & 0.004 & $\mathrm{~N}-\mathrm{M}, \mathrm{N}-\mathrm{C}$ \\
\hline Potassium content & 80.5 & $<0.001$ & $\mathrm{~N}-\mathrm{M}, \mathrm{N}-\mathrm{C}$ \\
\hline Sodium content & 0.4 & 0.708 & \\
\hline Silicate content & 245.4 & $<0.001$ & N-M, N-C, M-C \\
\hline Ash content & 29.2 & 0.001 & N-M, N-C, M-C \\
\hline Nitrate nitrogen content & 18.1 & 0.003 & N-C, M-C \\
\hline Crude protein content & 374.2 & $<0.001$ & N-M, N-C, M-C \\
\hline Crude fibre content & 5.6 & 0.042 & $\mathrm{~N}-\mathrm{C}$ \\
\hline Energy content & 221.3 & $<0.001$ & N-M, M-C \\
\hline
\end{tabular}



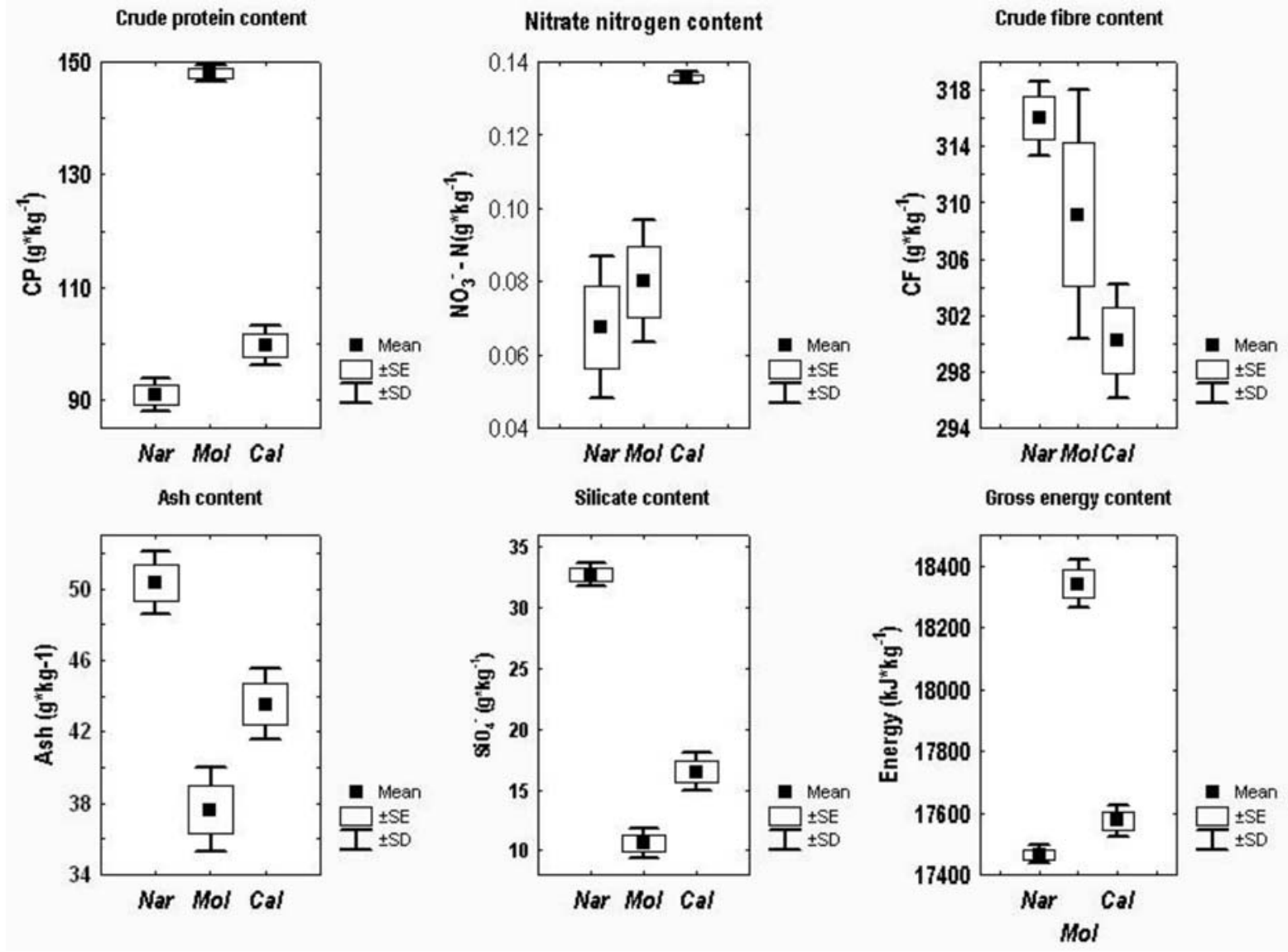

Fig. 5. Crude protein (CP), nitrate nitrogen, crude fibre (CF), ash, silicate $\left(\mathrm{SiO}_{4}^{-}\right)$, and gross energy contents in the biomass of Nardus stricta (Nar), Molinia caerulea $(\mathrm{Mol})$, and Calamagrostis villosa $(\mathrm{Cal})$.
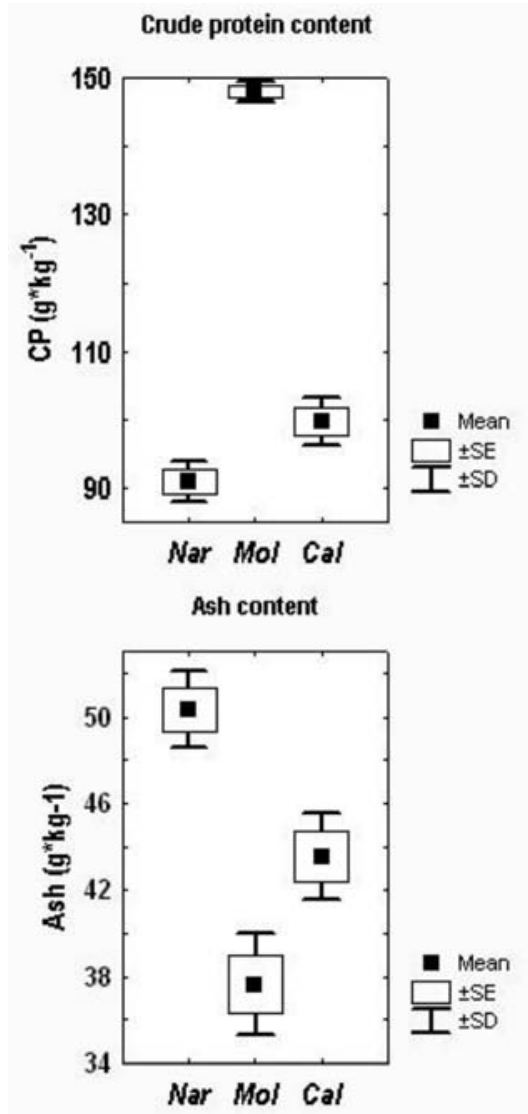
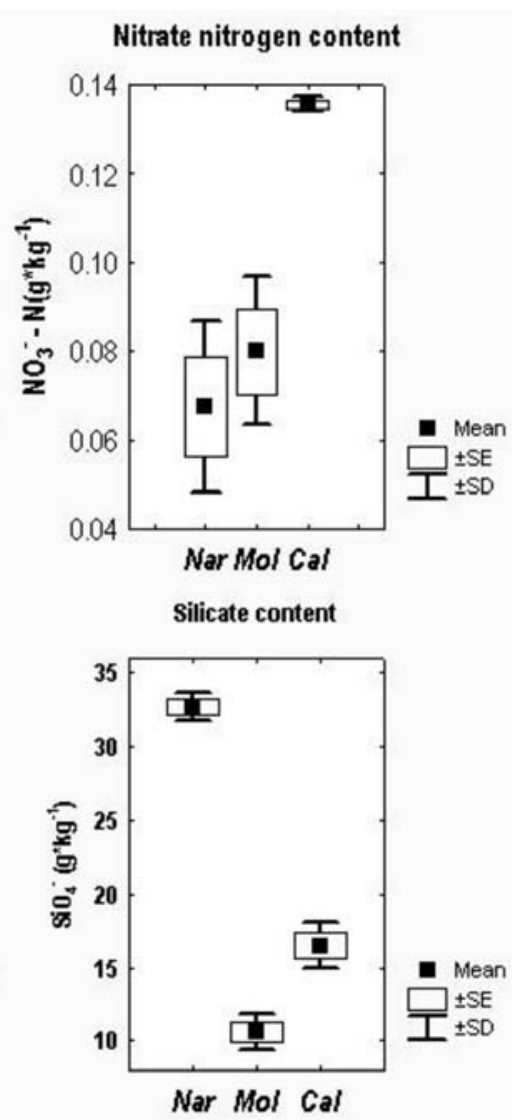
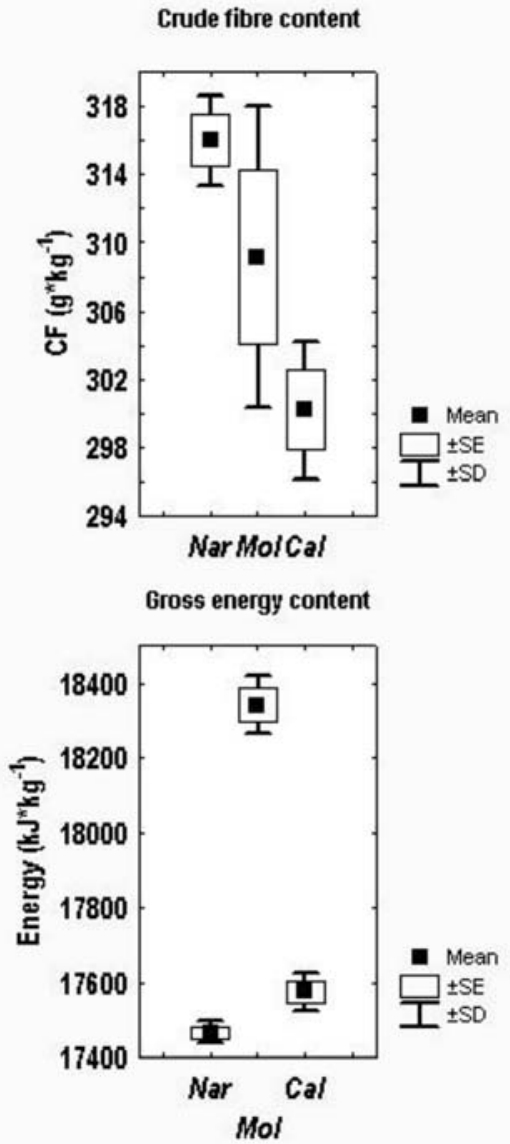

Fig. 6. Calcium, magnesium, phosphorus, potassium and sodium contents in the biomass of Nardus stricta (Nar), Molinia caerulea (Mol), and Calamagrostis villosa (Cal). 
Mean calcium content was $0.91,1.83$ and 1.58 , mean magnesium content $0.45,1.24$ and 0.53 , mean phosphorus content $0.85,1.19$ and 1.02 , mean potassium content $7.14,10.75$ and 11.72 , mean sodium content $0.08,0.11$ and $0.12 \mathrm{~g}^{*} \mathrm{~kg}^{-1}$ in $N$. stricta, M. caerule a and C. villosa biomass, respectively.

Although the contents of the mentioned macroelements important for animal production was the lowest in N. stricta forage, ash content was on the contrary the highest there. The high antinutritive silicate content in N. stricta fodder is responsible for converse ash results. Mean ash content was 50.33, 37.63 and 43.53 and mean silicate content 32.79, 10.58 and $16.47 \mathrm{~g}^{*} \mathrm{~kg}^{-1}$ in N. stricta, M. caerulea and $C$. villosa biomass, respectively. Nitrates were another investigated antinutritive compound. Although their content was the highest in $C$. villosa biomass, they were far under the toxic level for ruminants there. Mean nitrate nitrogen content was $0.07,0.08$, and $0.13 \mathrm{~g}^{*} \mathrm{~kg}^{-1}$ in N. stricta, $M$. caerulea, and $C$. villosa biomass, respectively.

Generally, the biomass quality of all investigated species was low and nutrients content was substantially lower than in forage from improved or most semi-natural grasslands in the Czech Republic. Based on nutrient content and content of antinutritive silicate, we concluded that $M$. caerulea possesses the best quality, which is only slightly different from $C$. villosa, and that $N$. stricta biomass is the worst of the investigated species.

\section{Nutrients removal}

The effect of vegetation type on nutrient removal was significant for all nutrients except sodium. Potassium and magnesium removal was significant for all three combinations of investigated stands. Total nitrogen, calcium, and phosphorus removal was significant only between $N$. stricta $-M$. caerulea and between $N$. stricta $-C$. villosa. Results of ANOVA analyses are shown in Table 4 and graphs in Figure 7.

Removal of all investigated nutrients was lowest in $N$. stricta dominated stand. This was caused by the lowest concentrations of nutrients in the biomass, but also by the lowest biomass yields. Mean nitrogen removal was 26.11,

TABLE 4. Results of ANOVA analyses of mineral removal in the harvested biomass from 1 ha of Nardus stricta, Calamagrostis villosa and Molinia caerulea dominated stands. For abbreviations see Table 2.

\begin{tabular}{|c|c|c|c|}
\hline Variable & F-ratio & P-value & Tukey HSD \\
\hline Nitrogen removal & 28.3 & 0.001 & $\mathrm{~N}-\mathrm{M}, \mathrm{N}-\mathrm{C}$ \\
\hline Calcium removal & 26.8 & 0.001 & N-M, N-C \\
\hline Potassium removal & 58.8 & $<0.001$ & N-M, N-C, M-C \\
\hline Phosphorus removal & 21.2 & 0.002 & N-M, N-C \\
\hline Magnesium removal & 109.6 & $<0.001$ & N-M, N-C, M-C \\
\hline Sodium removal & 1.5 & 0.289 & \\
\hline
\end{tabular}
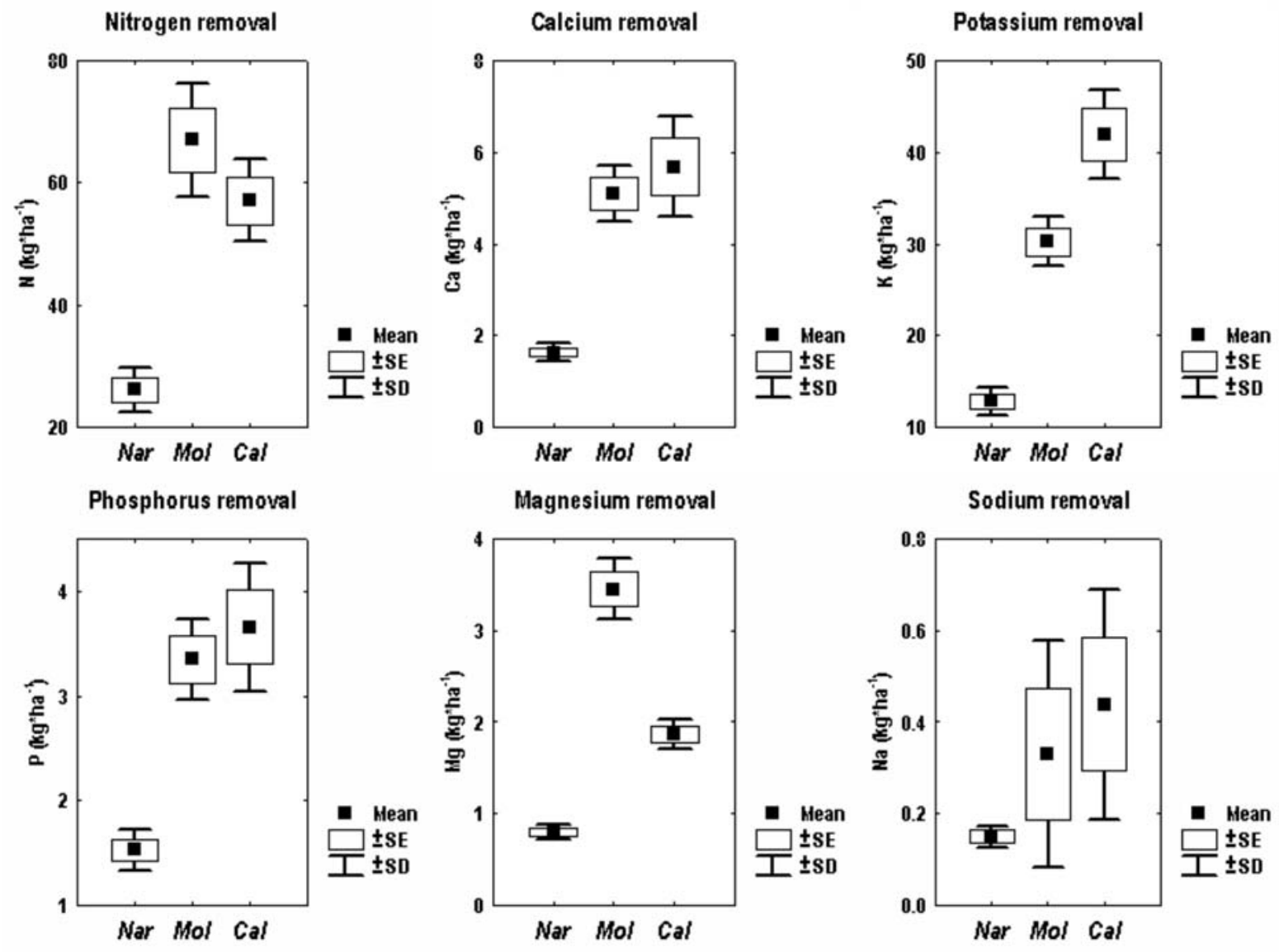

Fig. 7. Total nitrogen, calcium, potassium, phosphorus, magnesium and sodium removal in Nardus stricta (Nar), Molinia caerulea (Mol), and Calamagrostis villosa $(\mathrm{Cal})$ dominated swards. 
66.97, and 57.05, mean calcium removal 1.64, 5.10, and 5.68 , mean potassium removal $12.8,30.25$, and 41.93 , mean phosphorus removal $1.52,3.35$, and 3.66 , mean magnesium removal $0.80,3.45$, and 1.87 , and mean sodium removal was $0.15,0.33$, and $0.44 \mathrm{~kg}^{*} \mathrm{ha}^{-1}$ in N. stricta, $M$. caerulea, and $C$. villosa dominated swards.

\section{DISCUSSION}

\section{Mowing productivity and yields}

Differences in mown area per two minutes of mowing, similarly as obtained dry matter, indicate preferences of farmers for $C$. villosa and M. caerulea stands. These differences are determined by yields, and predominantly by mowing resistance of the investigated species. Mowing a $C$. villosa stand was relatively easy and almost all biomass above stubble height was removed without extraordinary effort. The opposite was recorded during mowing of the $N$. stricta sward and removing all biomass above the target stubble height was almost impossible. Mowing productivity was also affected by litter accumulation and it was impossible to mow only living organs there, particularly in the $N$. stricta sward. Our results concerning the difficulty of mowing $N$. stricta are in accordance with testimonies from the 19th century (Bartoš 1992). Short and very sharp scythes were necessary to harvest this grass not only in long-term unmanaged swards, but in regularly managed swards as well. Biomass production of $N$. stricta swards by mowing and without fertilizing was very low and hay-making reminded farmers more of shaving men's faces than harvesting grass (Štursa 1983). For its mowing difficulty, low yields and biomass quality, N. stricta was nicknamed "wolf-grass" in the Giant Mts. (Bartoš 1992; Kneifel 2004, pers. comm.). Mowing of "wolf-grass" was difficult for two reasons: 1) low sward height and therefore bending of leaves and stems during mowing; 2) characteristic high content of crude fibre and silicon compounds in the biomass. According to our unpublished experiences with regular harvesting of $N$. stricta sub-alpine swards, scything was difficult even if the area was cut annually and the proportion of litter was therefore low. Mowing of $M$. caerulea was of intermediate difficulty, particularly its relatively soft flexible leaves made it more difficult. We removed almost the all biomass above target height, but it consumed a fairly long time and therefore mowing productivity expressed in mown area per time was the same as in $N$. stricta. Mowing productivity of $M$. caerulea was intermediate and the higher obtained dry matter compared to $N$. stricta was caused especially by higher yields and a higher proportion of biomass removed by scything above the target stubble height. Differences in mowing productivity expressed in obtained dry matter are very considerable. The revealed yields were the lowest in the $N$. stricta sward. The yield recorded in our study was $1800 \mathrm{~kg}^{*} \mathrm{ha}^{-1}$, but yields of N. stricta grassland ranged from 200 to 800 $\mathrm{kg}^{*} \mathrm{ha}^{-1}$ above the upper tree limit in the 19th century (Bartoš 1992). Differences in the results are caused predominantly by previous management before yield estimation. In our case the sward had not been harvested for at least 60 years, thus the biomass production was high and approximately $40 \%$ of the harvested biomass was litter, while historical records refer to regular biomass harvesting which was carried out as frequent as possible. Harvest was possible only once per two or three years in the least productive stands of $N$. stricta. This indicates a rapid decrease of $N$. stricta stand productivity under regular defoliation without fertilization. The quick decrease in aboveground biomass production to $1 / 3$ of unmanaged grassland was reported by Moen et al. (1999) from mountain meadows in Norway. Recorded yields for M. caerulea and C. villosa with historical data could not be compared, because we cannot distinguish hay from this stands in the old records although using of these species for livestock feeding is documented in the literature (Reich 1907). According to historical economical records, hay-fields above the upper tree limit were divided into several quality categories and N. stricta hay was the worst (Bartoš 2000, pers. comm.). We can suppose that the other quality categories included $M$. caerulea and $C$. villosa hay. The response of $C$. villosa to regular defoliation was studied by Hejcman et al. (2005). Results showed a negative reaction of this species to mowing and indicate its probable retreat under long-term management. Based on mowing productivity and forage yields, we can conclude that farmers preferred $C$. villosa and $M$. caerulea swards and neglected $N$. stricta dominated grassland if they had the possibility to choose the sward type. This situation obviously occurred in times of extensive farming above the upper tree limit in the 16 th and 17 th centuries.

\section{Biomass quality}

According to Bartoš (1992), N. stricta hay was considered the worst of all available forage by farmers in the 19th century. It is remarkable that farmers' experiences are in accordance with modern analytical methods. Testimonies of old farmers (Kneifel 2004, pers. comm.) document very low milk production if cows were fed with $N$. stricta hay. Differences in forage quality of the three investigated species are high and consequently, farmers recorded the lowest animal performance if cows were fed with $N$. stricta. Biomass quality is affected by growth stage as well (Pavlů, Velich 1998) and therefore we collected samples under conditions of traditional hay-making to make our results best comparable with historical management. Crude protein content was the highest in the $M$. caerulea biomass. There are two reasons that explain this: 1) the effect of species as the main factor, because nutritive value is species specific, and 2) the effect of growth stage. $M$. caerulea was in the vegetative stage, stems were poorly developed in comparison with $N$. stricta and $C$. villosa in our study. It is generally known that younger biomass contains more nutrients than older in the same species. Nitrate nitrogen content was the highest in biomass of $C$. villosa. Although nitrates are considered to be antinutritive compounds, they did not affect fodder quality due to their very low concentrations in all investigated species. According to Čermák et al. (2000) concentrations of nitrate nitrogen up to $0.7 \mathrm{~g} * \mathrm{~kg}$ in dry matter are considered normal and have no toxic effect on ruminants. The maximum value recorded in our experiment reached only $0.14 \mathrm{~g}^{*} \mathrm{~kg}^{-1}$. All investigated macroelements necessary for animal performance had the lowest concentrations in $N$. stricta biomass in all cases. Fodder from Czech upland grasslands contains on average 6-7 $\mathrm{g}^{*} \mathrm{~kg}^{-1}$ of $\mathrm{Ca}$ and $3-4.5 \mathrm{~g}^{*} \mathrm{~kg}^{-1}$ of $\mathrm{P}$ in dry matter (Pavlů 1994; Pavlů, Velich 1998). In comparison with species investigated in our study we can conclude that all species ha- 
ve a low content of macroelements, but $N$. stricta biomass has the lowest. On the other hand, the highest ash content was found in biomass of $N$. stricta. The high silicon content was responsible for that. Silicon compounds are antinutritive because they decrease enzymatic activity and form a mechanical barrier for digestion and therefore grasses with a high silicon content such as in $N$. stricta possess a low biomass utilization by livestock (Kalač, Míka 1997; Čermák et al. 2000). Crude fibre content, similarly as silicon content, was also the highest in the biomass of $N$. stric$\mathrm{ta}$. Excessive fibre content is responsible for a decrease of fodder intake and digestibility (Míka et al. 1997). From this point of view $N$. stricta produced the worst fodder, although we analyzed the biomass produced in the year of investigation, not the accumulated litter.

Based on the analysis of nutritive value, it is evident that $N$. stricta has the worst forage quality, $C$. villosa has a better one, and $M$. caerulea is the best of three investigated species. If the farmer had the possibility to choose the sward type for hay-making, he obviously preferred M. caerulea or $C$. villosa and neglected $N$. stricta sward.

\section{Nutrient removal}

Nutrient removal was the lowest in the N. stricta dominated sward. N. stricta was evidently the least nutrient demanding species there. According to Krahulec et al. (1996) $N$. stricta was able to spread into the least productive grasslands in the montane zone of the Giant Mts. during the long-term process of regular mowing without fertilization and consequently oligotrophisation. $N$. stricta is also the least nutrient demanding species above the upper tree limit. Based on nutrient removal replacement of $C$. villosa and $M$. caerulea stands by $N$. stricta dominated swards can be supposed due to harvesting without fertilization in the subalpine vegetation zone. Although higher nitrogen deposition is generally considered as the main cause of M. caerulea and $C$. villosa spread in the last few decades, other nutrients necessary for plant growth are not taken into account by this theory. It is evident that the contents of other nutrients in the biomass of M. caerulea and C. villosa is higher than in $N$. stricta and together with higher yields of these stands, mowing resulted in an increasing removal of nutrients and therefore probably in a quick decrease in soil fertility there. With respect to these facts, the competitive advantage of $N$. stricta is obvious under long-term mowing without fertilization. In consequence, the recent increase of $M$. caerulea and $C$. villosa above the upper timber line can at least partly be explained as a succession of $N$. stricta swards after cessation of defoliation activities. Small patches of several metres in diameter are characteristic of early stages of $M$. caerulea spread into $N$. stricta grassland. These patches are widely dispersed in N. stricta grassland where we can not suppose different soil conditions.

\section{General synthesis}

Analysis and comprehension of farmer decision making and historical agricultural activities are the crucial factors in evaluating development or origin of many plant communities. Farmers seek to increase livestock production by feeding high quality fodder and by harvesting the most productive stands if the time for harvesting is limited or by harvesting all plant communities without respect to fodder quality in the case of a limited area available for hay-making. Harvesting of only $C$. villosa and $M$. caerulea stands of the highest production and quality was probably performed in the era of extensive agriculture in the 16th and 17th centuries. All stands were harvested in the 18th, 19th, and 20 th centuries. With respect to nutrient removal revealed in our study, the retreat of $C$. villosa and $M$. caerulea dominated stands in favour of $N$. stricta above the upper tree limit in the Giant Mts. is obvious. This hypothesis is in accordance with conclusions by Lokvenc (1960) and Hendrych (2001) about a quick increase of $N$. stricta in the past due to agricultural activities. This theory is supported by the high sensitivity of $C$. villosa and $M$. caerulea to defoliation (Grant et al. 1996; Hejcman et al. 2005; Pospíšilová 2005) and by $N$. stricta seedling recorded in Calamagrostion villosae grassland mown for several years (Hejcman, unpublished data). Based on historical records, fertilization was never practised in the Labská and Harrachov meadow localities and the area was divided into regular hay-fields in the era of intensive agriculture from the 18th century onwards and rented out for 6 years to farmers in auctions (Lokvenc 2001). Because farmers paid for renting of the area (the area for harvest was limited at the time), they removed as much biomass as possible without respect to its quality. A forestry commission was delegated to control and record mowing activities and keeping the agreed conditions. High year-to-year variability in biomass production is visible from the old economic records. For example $20.1 \mathrm{t}$ of hay was harvested in the Čertova meadow near Luční bouda chalet in 1814, but more than twice, $45.08 \mathrm{t}$ of hay in 1819 , five years later. Harvesting these $N$. stricta stands of low production and quality for livestock feeding is indisputable evidence for a maximum pressure on the mountains by livestock and therefore maximum forage demand and very intensive land use in the 18th and 19th centuries. Fertilized hay-fields were only present in the eastern sub-alpine plateau of the Giant Mountains in the neighbourhood of Scharfova, Stará, Pramenná, Gottsteinova, and Luční bouda chalets (Lokvenc 1990, Hartmanová 2002). The border between mown and manured, most often dominated by $D e$ schampsia cespitosa or Polygonum bistorta at present, and only mown, dominated by N. stricta, is still sharp (accurate to a few metres) and very well recognizable although the mowing and manuring ceased several decades ago. It is obvious that all agricultural activities are long-time evident in subalpine conditions and that they must be taken into account into analyses of grassland succession there. Consequently, the recent increase of defoliation sensitive species $M$. caerulea and $C$. villosa above the timber line must be evaluated with respect to both: termination of agricultural activities and elevated nitrogen deposition.

\section{ACKNOWLEDGEMENTS}

The paper is dedicated to Ing. Theodor Lokvenc, CSc. for his life work devoted to the history of the Giant Mts. The study was supported by grant MZP VaV 620/04/03. We are grateful to Martin Černý for help with the fieldwork, Dr. František Krahulec, Dr. Jan Štursa, Ing. Jan W. Jongepier and two reviewers for their useful comments. 


\section{LITERATURE CITED}

AOAC 1984. Official methods of analysis. 14th ed. Association of official analytical chemists, Washington.

BARTOŠ M. 1991. Z historie bud na Čertově louce. Krkonoše 2: 27-29. (in Czech)

BARTOŠ M. 1992. Vzpomínky na senoseč. Krkonoše 8: 16-17. (in Czech)

ČERMÁK B., KADLEC J., MUDŘÍK Z., LÁD F., SUCHÝ P., ŠOCH M., ZEMAN L. 2000. Základy výživy a krmení hospodářských zvírrat. Zemědělská fakulta Jihočeské univerzity, České Budějovice. (in Czech)

FABISZEWSKI J., WOJTUN B. 2001. Contemporary floristic changes in the Karkonosze Mts. Acta Soc. Bot. Pol. 70: 237-245.

GRANT S.A., TORVELL L., COMMON T. G. SIM E. M., SMALL J.L. 1996. Controlled grazing studies on Molinia caerulea grassland: effects of different seasonal patterns and levels of defoliation on Molinia growth and responses of sward to controlled grazing by cattle. J. Appl. Ecol. 33: 1267-1280.

HARTMANOVÁ O. 2002. Novověké osídlení Krkonoš z pohledu archeologie. MSc. Thesis, Fakulta humanitních studií, Západočeská univerzita, Plzeň. (in Czech)

HEJCMAN M., PAVLŮ V., GAISLER J., KLAUDISOVÁ M., NEŽERKOVÁ P., PAVLŮ L. 2005. Spread and control of Calamagrostis villosa above the upper tree limit in the Giant Mts., Czech Republic. Grassland Science in Europe 10. Proceedings of the 21th general meeting of the European Grassland Federation, Tartu, Estonia 61-64.

HEJCMAN M., NEŽERKOVÁ P., PAVLŮ V., GAISLER J., LOKVENC T., PAVLŮ L. 2005. Regeneration of Nardus stricta subalpine grasslands in the Giant Mountains (Krkonoše). Acta Soc. Bot. Pol. 74: 253-258.

HEJDUK S., DOLEŽAL P. 2004. Nutritive value of broad-leaved dock (Rumex obtusifolius L.) and its effect on the quality of grass silages. Czech J. Anim. Sci. 49: 144-150.

HENDRYCH R. 2001. Květena - Krkonoš zvláště - před čtyřmi staletími. Preslia 73: 29-58. (in Czech)

HOMOLKA P. 2000. Produkce nadzemní biomasy a její stravitelnost přežvýkavci u pastevního porostu na Zadních Rennerovkách v Krkonoších. Opera Corcontica 36: 559-562. (in Czech)

JENÍK J. 1961. Alpinská vegetace Vysokých Sudet: Teorie anemo-orografických systémů. Academia, Praha. (in Czech)

JANČOVIČ, J., HOLÚBEK, R., 1999. Some quality parameters of chosen meadow plant species after long-term fertilization of semi-natural grassland. Rostl. Výroba 45, 79-83.

KALAČ P., MÍKA V. 1997. Přirozené škodlivé látky v rostlinných krmivech. ÚZPI, Praha. (in Czech)

KOČÍ M. 2001. Subalpine tall-forb vegetation (Mulgedio-Aconitetea) in the Czech Republic: syntaxonomical revision. Preslia 73: 289-331.

KRAHULEC F. 1985. The chorologic pattern of European $\mathrm{Na}$ rdus-rich communities. Vegetatio 59: 119-123.

KRAHULEC F., BLAŽKOVÁ D., BALÁTOVÁ-TULÁČKOVÁ E., ŠTURSA J., PECHÁČKOVÁ S., FABŠIČOVÁ M. 1996. Louky Krkonoš: Rostlinná společenstva a jejich dynamika. Opera Concortica 33: 3-250. (in Czech)

KUBÁT K., HROUDA L., CHRTEK J. JUN., KAPLAN Z., KIRSCHNER J., ŠTĚPÁNEK J. (eds). 2002. Klíč ke květeně České republiky. Academia, Praha. (in Czech)
LOKVENC T. 1960. Krkonošské hřebeny. Nakladatelství krajského domu osvěty, Hradec Králové. (in Czech)

LOKVENC T. 1978. Toulky krkonošskou minulostí. Kruh, Hradec Králové. (in Czech)

LOKVENC T. 1990. Čertova louka. Krkonoše 6: 27-29. (in Czech)

LOKVENC T. 1996. Klečový vegetační stupeň a jeho problémy. In: Vacek S. (ed.) Monitoring výzkum a management ekosystémů na území Krkonošského národního parku, p. 224-228, Výzkumný ústav lesního hospodářství a myslivosti, Opočno. (in Czech)

LOKVENC T. 2001. Budní hospodářství Labské louky. Z Českého ráje a Podkrkonoší 14: 69-90. (in Czech)

MARRS R.H., PHILLIPS J.D.P. TODD P.A., GHORBANI J., LE DUC M.G. 2004. Control of Molinia caerulea on upland moors. J. Appl. Ecol. 41: 398-411.

MÍKA V., HARAZIM J., KALAČ P., KOHOUTEK A., KOMÁREK P., PAVLŮ V., POZDÍŠEK J. 1997. Kvalita píce. Ústav zemědělských a potravinářských informací, Praha. (in Czech)

MOEN A., NILSEN L.S., OIEN D., ARNESEN T. 1999. Outlying haymaking lands at Solendet, central Norway: effects of scything and grazing. Norsk Geogr. Tidsskr. 53: 93-102.

PAVLŮ V., HEJCMAN M., PAVLŮ L., GAISLER J., NEŽERKOVÁ P. 2006. Effect of continuous grazing on forage quality, quantity and animal performance. Agric. Ecosys. and Environ. 113: 349-355.

PAVLŮ V., VELICH J. 1998. The quality of pasture forage under rotational and continual grazing of heifers. Rost. Výroba 44: 287-292.

PAVLŮ V., VELICH J. 2001. The effect of rotational and continuous grazing on sward. Rost. Výroba 47: 154-159.

PAVLŮ V. 1994. Content of mineral substances in pasture herbage in relation to requirements of cattle. Rost. Výroba 40: 209$-217$.

POSPIŚIILOVÁ K. 2005. Dynamika šîření bezkolence modrého nad horní hranicí lesa v Západních Krkonoších, Mgr. thesis. Pedagogická fakulta, Univerzita Hradec Králové, Hradec Králové. (in Czech)

REICH E. 1907. Lukařství. Knihovna Milotického hospodáře,Valašské Meziříčí. (in Czech)

SCHELLBERG J., MOSELER B.M., KUHBAUCH W., RADEMACHER I.F. 1999. Long-term effects of fertilizer on soil nutrient concentration, yield, forage quality and floristic composition of a hay meadow in the Eifel Mountains, Germany. Grass and Forage Sci. 54: 195-207.

SCHMID L. 1879. Statisticko-topografický popis velkostatku Jilemnice. Praha. (in Czech)

ŠTURSA J. 1983. Poušt na hřebenech. Krkonoše 2: 16-19. (in Czech)

ŠTURSOVÁ H. 1985. Antropické vlivy na strukturu a vývoj smilkových luk v Krkonoších. Opera Corcontica 22: 79-120. (in Czech)

TOMASSEN H.B.M., SMOLDERS J.P., LIMPENS J., LAMERS L.P.M., ROELOFS G.M. 2004. Expansion of invasive species on ombrotrophic bogs: desiccation or high $\mathrm{N}$ deposition? J. Appl. Ecol. 41: 139-150.

WÁGNEROVÁ Z. 1991. Rostlinná společenstva Kotelních jam a jižního svahu Krkonoš v rozmezí let 1968-1990, Ms. Habilit. Thesis., depon. in Přír. Fak. MU Brno. (in Czech). 